\title{
POLISH VERSUS EUROPEAN BANKING SECTOR - CHARACTERISTICS, CONSOLIDATION, OWNERSHIP CHANGES
}

\author{
Anna PYKA (D, Aleksandra NOCOŃ (D* \\ Department of Banking and Financial Markets, Faculty of Finance and Insurance, \\ University of Economics in Katowice, 1 Maja 50, 40-287, Katowice, Poland \\ *E-mail: aleksandra.nocon@ue.katowice.pl
}

\begin{abstract}
Purpose - the main aim of the study is an assessment of the banking sector in Poland, including the size of the sector, banking institutions forming the sector and consolidation processes taking place in the sector against the background of banking sectors in other countries. The paper also indicates ownership changes as a consequence of consolidation processes in the banking sectors after the global financial crisis of 2008-2012.
\end{abstract}

Research methodology - the following research methods were used: cause and effect analysis, comparative analysis, case studies, observation method, secondary data analysis, and synthesis method.

Findings - the research allowed to find out that the banking sector in Poland is growing at a rate significantly exceeding the growth rate in other European countries. However, rapid development does not mean a radical increase in the importance of this sector in Europe. Concentration ratios of the Polish banking sector show continuous but slight increases, although their level is still quite low compared to other European Union countries. Moreover, in Poland, a decreasing number of banks, observed in recent years, reduces a share of foreign investors in the structure of the sector. This means a high activity of domestic investors in taking over bank capital.

Research limitations - the main research limitation is that the study mainly focuses on changes as well as comparative analysis of the concentration ratio (CR5). While further research should be expanded by more measures to compare ownership structure and the profitability of Polish and the European Union's banking sectors.

Practical implications - the results might be useful for central banks and supervisory authorities when it comes to their role in changes in the ownership structure of banking sectors.

Originality/Value - the main value of the article is the in-depth analysis of the ownership structure of the Polish banking sector in the background of the European ones.

Keywords: financial system, banking sector, banking assets, banking consolidation processes, the degree of concentration, bank's ownership.

JEL Classification: G21, G32, G34.

Conference topic: Contemporary Financial Management.

\section{Introduction}

The banking sector is very important for the financial system and the real economy. A share of banks' assets in the financial system in the European countries and in the world is diverse. It is varied from the point of view of the value of bank assets, profitability, the degree of sector's concentration as well as its ownership structure. The main aim of the study is an assessment of the banking sector in Poland, including the size of the sector and banking institutions forming the sector. The banking sector is constantly changing - both in the world, in Europe as well as in Poland. These changes are accompanied, among others, by consolidation process and ownership changes. This is a reason that the paper also indicates consolidation processes taking place in the sector against the background of banking sectors in other EU countries. The consequences of the consolidation process can be considered in many areas, including a concentration level, which might be measured by different ratios. However, due to the limited scope of the paper, the Authors concentrate their attention on consequences of the consolidation, measured by the total assets of the 5 largest banks (CR5) in the banking sector in Poland and in the European Union.

The decreasing number of banks in Poland, observed in recent years, reduces a share of foreign investors in the sector's structure. This means the high activity of domestic investors in taking over bank capital. The main value of 
the article is an in-depth analysis of the ownership structure of the Polish banking sector in the background of the European ones. Further research might be expanded by also other measures to compare ownership structure and profitability of Polish and the European Union's banking sectors.

The following research methods were used: cause and effect analysis, comparative analysis, case studies, observation method, secondary data analysis, and synthesis method.

\section{Theoretical background - a literature review}

The banking sector is the major element of the financial system that also plays a key role in the real economy. A share of banks' assets in the financial system in the European countries and in the world is diverse, although in some countries (including Poland) it constitutes over $2 / 3$ of the total assets of the whole financial sector. This means that the banking sector stability is crucial for the stability of the whole financial system. The value of bank assets, the degree of sector's concentration as well its ownership structure have a multidirectional effect not only on the financial sector but also on the whole real economy of the country. Most empirical research confirms that banking sector development is an important factor affecting the country's economic growth (Al-Malkawi, Marashde, \& Abdullah, 2013; Greenwood, Sanchez, \& Wang, 2013; Tsaurai, 2017).

A common feature of all banking sectors in the world as well as in Europe is the ongoing consolidation process of the banking sector, which is defined as a multi-stage process of ownership, capital and organizational transformations, determined by changes taking place in the global economy (Seo \& Hill, 2005). In the face of globalization, banks faced the problem of increasing efficiency of their operations and improving their competitiveness (Flejterski \& Wahl, 2010). For this purpose, they constantly undertake actions aimed at increasing efficiency of their operating activity, through the optimization of organizational structures, employment, sales network (...). These processes are strengthened by mergers and acquisitions made in recent years as well as the development of electronic banking. It is considered that consolidation contributes to the banking system stabilization (Berger, Demsetz, \& Strahan, 1999; Financial Service Agency, 2002; Shih, 2003). Kurgan-van Hentenryk shows that many of the governments of European countries, including Austria, Belgium, and Germany, promoted bank consolidations when the financial system was exposed to banking crises in the 1920s and 1930s (Pohl, Tortella \& Van der Wee, 2001). On the other hand, most of the empirical literature suggests that bank consolidations do not significantly improve the performance or efficiency of the participating banks (Berger et al., 1999). The main motives for the progressive consolidation of banking sectors include (Kotowicz, 2015):

- operational efficiency issues - a need to achieve an appropriate level of scale of activity or to find a profitable niche,

- issues of decreasing profitability of operations along with a growth of the economy and financial system,

- decisions to exit a domestic market by foreign banks, due to failure to achieve the assumed level of scale of activity,

- organizing group structures.

Consolidation in the banking industry is driven by technological advances, globalization of financial services markets and operations to increase efficiency, reduce costs or gain competitive advantage. Besides the effects of these economic factors, the pace of consolidation has accelerated because of the easing of regulatory discipline on the ability of banking organizations to expand geographically and to establish banking offices, although some legal regulations, including federal antitrust laws, continue to restrict potential changes. Consolidation may not only affect the behavior of parties involved but may also have implications for other market participants. For example, consolidation may affect the competitive interaction among lending institutions in the market, with possible implications for market performance (Avery, Bostic, Calem, \& Canner, 1999; Jackson, 2018).

For senior management in European banks, increasing costs and squeezed margins due to regulatory pressures and low-interest rates are increasingly the strongest arguments for trying to achieve higher market shares. Ever-faster changes in technological advances and a need to keep up with the latest developments and security requirements are other factors inclining to consolidation (Europe primed for..., 2018). Moreover, under conditions of the Polish economy, the above-mentioned consolidation premises were also affected by (Kotowicz, 2015):

- taking over weak banks, established at the beginning of the transformation process,

- consolidation of the cooperative banking sector,

- banking sector privatization,

- direct and indirect consequences of the financial crisis,

- effects of international acquisitions,

- an increase of the scale of activity of large banks exceeding the growth of the sector's scale.

The consequences of consolidation process can be considered in many areas, including a concentration level, measured by 5 and/or 10 largest banks in the sector (CR - concentration ratio), a level of deposits, a level of loans, capital adequacy ratios, effectiveness ratios (ROA, ROE, C/I), a status of systemically important financial institution. 
The ongoing consolidation process of banking sectors, as a result of the global financial crisis and instability of some financial institutions, has contributed to changes in the ownership structure. The change in ownership structure in European banking sectors, including Poland, was determined mainly by (Kotowicz, 2015):

- a change in the geographic distribution of strategic investors,

- an increase of domestic investors' share in the banking sector's total assets,

- taking over weaker institutions by those with stronger financial position.

A considerable part of the research is devoted to the relationship between the efficiency of banks and their ownership (Horvatova, 2018). Many studies conclude that the privatization of state-owned banks increased the efficiency of banks in CEE countries (Hasan \& Marton, 2003; Matoušek \& Taci, 2004). Doan, Lin, and Doong (2018) evaluated bank efficiency by combining two interrelated dimensions: bank income diversification and ownership of banks.

\section{Methodology and empirical findings}

The research methodology was based on analysis and assessment of changes in the ownership structure of the Polish banking sector on the background of the European ones. It has been divided into two stages. The first stage included the analysis of size and development of the Polish banking sector also compare it to the selected banking sectors of the European Union countries. While the second stage was based on the assessment of the consequences of consolidation process from the point of view of its concentration level. Concentration is defined as a measure of subject participation in cumulative sales, assets or market share and it is usually determined by the number of companies in an industry and by their relative size (Zingales \& Raghuram, 2003). The importance of market concentration in the banking sector is reflected in its impact on competition, efficiency, and profitability in the banking sector, as well as on economic development and structure in other sectors.

The most common measure on banking sector concentration is a concentration ratio, which represents the sum of sector shares of k-participants with highest shares. There is no rule for choosing an appropriate value of $\mathrm{k}$, but it usually amounts to 5 or 10 banking sectors' participants. The concentration ratio (CR) takes the following formula (Jansen \& de Haan, 2003):

$$
C R_{k}=\sum_{i=1}^{k} s_{i},
$$

where: $s_{i}$ - are market shares of $k$ largest banks in the market.

The basic advantage of this ratio is that it is relatively easy to calculate. On the other hand, the main disadvantage is that it does not use information about the market share of all market participants (Jansen \& de Haan, 2003). In the research, it was used CR5 ratio to illustrate a share of 5 largest banks in total assets of the Polish banking sector (CR5) in 2008-2017 and then compare the results to other EU sectors. In the last part, the research consisted of the comparative analysis of a share of domestic capital in the total assets of Polish as well as selected European banking sectors, indicating the carried out Repolonization process in Poland.

During the study, the following research methods were also used: cause and effect analysis, comparative analysis, case studies, observation method, secondary data analysis, and synthesis method.

In recent years, the Polish banking sector has been one of the fastest growing among all European Union member states. The value of banking institutions' assets in Poland in the third quarter of 2018 exceeded 435 bln EUR (over $70 \%$ of the whole financial sector), which majority, over 394 bln EUR, was represented by commercial banks (see Table 1). The whole banking sector during the 9-months of 2018 compared to the same period of the previous year has shown growth dynamics at a level of $107 \%$.

Table 1. Assets of the main banking system institutions in Poland in the years of 2014/2018 (source: own work based on Polish Financial Supervision Authority, 2015, 2016, 2017, 2018a, 2018b, 2018c)

\begin{tabular}{|l|c|c|c|c|c|c|c|c|}
\hline & \multicolumn{7}{|c|}{ Value (bln EUR)* } & \multicolumn{2}{c|}{$\begin{array}{c}\text { Dynamics - } \\
\text { September } \\
2018 \text { versus } \\
\text { September } \\
2017\end{array}$} & $\begin{array}{c}\text { Structure - } \\
\text { September } \\
2018\end{array}$ \\
\hline & $09 / 2014$ & 2015 & 2016 & $09 / 2017$ & 2017 & $09 / 2018$ & $107 \%$ & $100 \%$ \\
\hline $\begin{array}{l}\text { The banking sector, } \\
\text { including: }\end{array}$ & 356.3 & 372.1 & 413.3 & 407.7 & 413.2 & 435.4 & $107 \%$ \\
\hline Commercial banks & 324.3 & 339.1 & 361.4 & 368.7 & 372.6 & 394.1 & $107 \%$ & $91 \%$ \\
\hline $\begin{array}{l}\text { Credit institutions } \\
\text { branches }\end{array}$ & 7.7 & 7.4 & 8.5 & 9.9 & 10.4 & 10.4 & $105 \%$ & $2 \%$ \\
\hline \begin{tabular}{l} 
Cooperative banks \\
\hline
\end{tabular} & 24.4 & 25.5 & 28.1 & 29.0 & 30.2 & 31.0 & $107 \%$ & $7 \%$ \\
\hline
\end{tabular}

*For calculations were adopted the following exchange rates: EUR / PLN $=4.30$. 
As Figure 1 shows, banking sector assets in Poland until the mid-1990s did not exceed 20 bln EUR. In 1999, the value of the sector's total assets was over 84 bln EUR, while in 2004 assets exceeded 125 bln EUR, and in 2017 it was 185 bln EUR. This means more than an 11-fold increase in the value of its total assets over 26 years. The largest increase in total assets (these were mainly value of loans) was recorded by banks after 2008 - the average annual growth in the years of 200-2017 amounted to 23 bln EUR ${ }^{1}$.

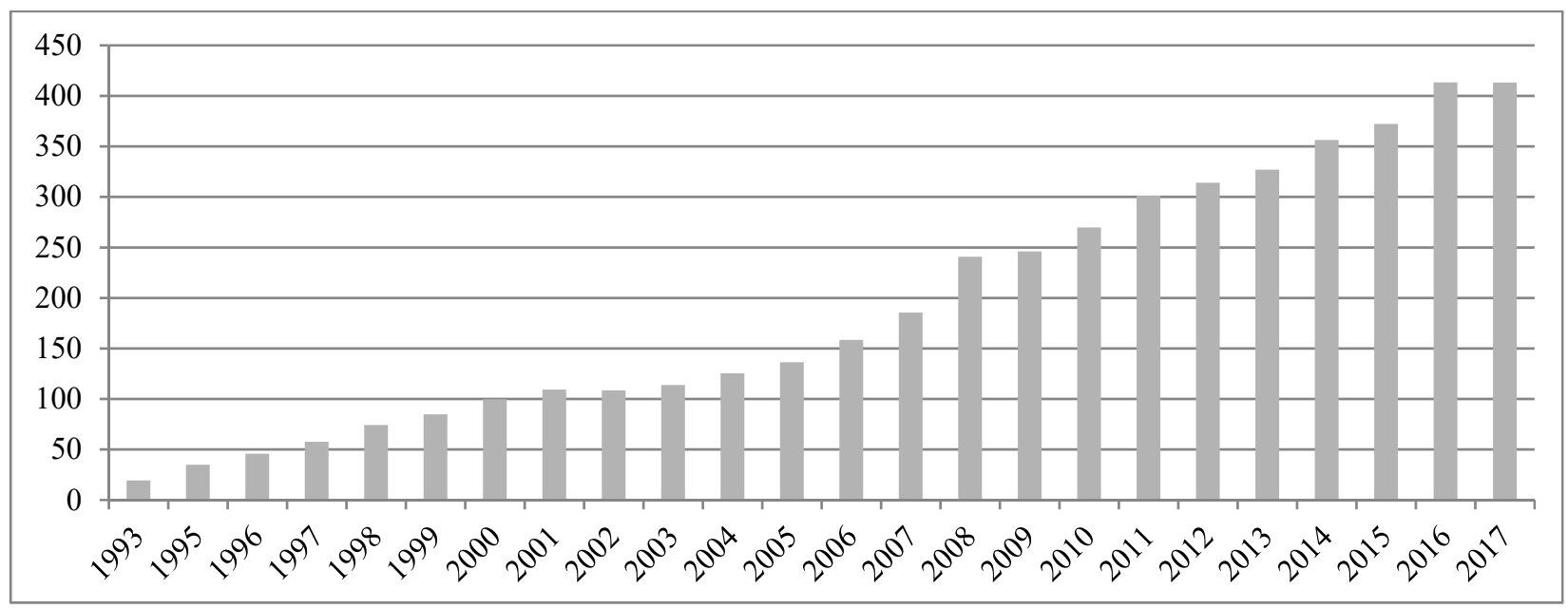

*For calculations were adopted the following exchange rates: EUR / PLN $=4.30$

Figure 1. Total assets of the Polish banking sector in the years of 1993-2017 [in bln EUR] (source: own work based on National Bank of Poland, 2000, 2007; Polish Financial Supervision Authority, 2007-2017)

No other country within the Eurozone was nor experienced such dynamic growth at the same time. In the period 2010-2016, only four of the 19 EU Member States, belonging to the euro area, were recorded any increase. In other countries, the value of total assets accumulated by local banks decreased.

Table 2. The change in total assets of banking sectors in selected countries of the world in 2010-2016 (source: ECB, FED and Polish Financial Supervision Authority data)

\begin{tabular}{|c|c|c|c|}
\hline State & Change (increase) & State & Change (decrease) \\
\hline Poland & $65 \%$ & & $-8 \%$ \\
\hline Finland & $41 \%$ & Euro area & $-17 \%$ \\
\hline United States & $38 \%$ & Austria & $-18 \%$ \\
\hline Slovakia & $40 \%$ & Germany & $-24 \%$ \\
\hline France & $14 \%$ & Portugal & $-24 \%$ \\
\hline Italy & $0 \%$ & Estonia & $-27 \%$ \\
\hline & & Slovenia & $-39 \%$ \\
\hline & & Greece & $-53 \%$ \\
\hline & & Cyprus & $-67 \%$ \\
\hline
\end{tabular}

As shown in Table 2, in the years of 2010-2016, the value of total assets of the German banking sector, which is one of the three pillars of European banking market - alongside France and the United Kingdom, has shrunk by as much as $18 \%$. Bankers from Cyprus, Slovenia, Portugal, and Estonia experienced an even greater decline. However, the biggest drops were recorded in Ireland - during just seven years, the total assets of local banks have decreased by almost 70\%. Against the background of the shrinking amount of euro area assets, only Finland and Slovakia currently stand out positively, with an increase of $40 \%$ since 2010 . In the analyzed period, the value of the total assets of the Polish banking sector increased by $65 \%$.

Despite the rapid growth, the Polish banking sector still plays a marginal role on a global scale (see Table 3). In January 2018, a share of banks, operating in Poland, in the total assets of the EU banking sector was less than $1.5 \%$. For comparison - assets of banks operating in Poland are over 22 times smaller than the value of total assets in

${ }^{1}$ The nominal increase in the banking sector's assets in Poland was also accompanied by its strengthening in relation to the national country. In the initial period of changes in the banking sector, a share of total assets of all banks (commercial as well as cooperative ones) in relation to GDP of Poland did not exceed 50\%, while in 2016 the sector's total assets in relation to GDP of Poland was amounted to $92 \%$ and it was the highest level in history. However, the ratio of banking sector assets to GDP is much lower than on banking market of highly developed countries (in the Netherlands, Sweden or Switzerland banks' total assets are already more than three times higher than their annual GDP). 
balance sheets of banks operating in the United Kingdom, while compared to France or Germany, the banking sector in Poland represents only $6 \%$ credit institutions assets in those countries.

The figures in Table 3 show that the size of banks' assets in Poland is even lower compared to much smaller countries, such as Austria, Belgium or the Netherlands. In relation to the Netherlands, it is more than 7 times less, or not much more in comparison to Greece - strongly hit by the recent crisis (before the global financial crisis in 2008 a share of the Polish banking sector was less than $0.7 \%$ ).

Table 3. The Polish banking sector in comparison to other European Union countries (source: own work based on ECB, FED, Polish Financial Supervision Authority and Eurostat data)

\begin{tabular}{|c|c|c|}
\hline Country & Total assets (tln EUR) & Calculated per capita (in thous. EUR) \\
\hline Euro area & 28 & 82 \\
\hline United States & 14 & 41 \\
\hline United Kingdom & 9 & 85 \\
\hline Germany & 7 & 104 \\
\hline France & 7 & 79 \\
\hline Spain & 4 & 45 \\
\hline Italy & 3 & 149 \\
\hline The Netherlands & 3 & 121 \\
\hline Austria & 1 & 1350 \\
\hline Luxembourg & 0.8 & 100 \\
\hline Finland & 0.5 & 101.0 \\
\hline Ireland & 0.5 & 39 \\
\hline Portugal & 0.4 & 11 \\
\hline Poland & 0.4 & 33 \\
\hline Greece & 0.3 & EUR/ PLN \\
\hline
\end{tabular}

* As at the end of 2016. For calculations were adopted the following exchange rates: EUR / USD $=1.17$ and EUR / PLN $=4.30$.

The Polish banking sector is even more negligible, taking into account differences in the population. Having regard to the fact that Poles constitute almost $8 \%$ of whole EU citizens, less than $2 \%$ of the share of the Polish banking sector in the structure of total assets of the European sector shows how many divides Poland from other Community countries. In this comparison, Poland has the worst figures in relation to Luxembourg. The assets of local banks per capita in Luxembourg are almost 150 times higher than in Poland (however, it is worth remembering the special role that Luxembourg plays on the European and global finance map).

Analyzing banking sector in Poland against the background of other countries' sectors, it should be taken into account the fact that Polish banking in terms of the free market economy has a much shorter history rather than other most highly developed economies. In Poland, commercial banking developed at the beginning of the 90s of the twentieth century (I. Pyka, Cichy, Nocoń, \& A. Pyka, 2018). Thus, apart from first years after the transformation, its functioning can be considered as a period of merely 20-25 years, while the banking services market in Germany, France, Italy or Switzerland has a several-hundred-year tradition. In this case, comparing sectors' sizes may not present an objective view of the situation.

Table 4. The banking sector in Poland versus banking sectors of Central and Eastern European countries as at December 31, 2017 (source: own work based on ECB, BNB, CNB, RNB, SNB, Polish Financial Supervision Authority, and Eurostat data, https://www.najlepszekonto.pl/sektor-bankowy-w-polsce-i-za-granica 2019, February)

\begin{tabular}{|c|c|c|}
\hline Country & Bank assets (in bln EUR)* & Calculated per capita (in thous. of EUR)* $^{*}$ \\
\hline Poland & 430 & 24 \\
\hline Czech Republic & 280 & 11 \\
\hline Hungary & 115 & 5 \\
\hline Romania & 90 & 12 \\
\hline Slovakia & 73 & 7 \\
\hline Bulgaria & 48 & 16 \\
\hline Latvia & 30 & 8 \\
\hline Lithuania & 26 & 16 \\
\hline Estonia & 25 & \\
\hline
\end{tabular}

*For calculations were adopted the exchange rate valid for January 2018. 
Banking sectors of Central and Eastern European countries, such as Slovakia, Romania, Hungary or the Baltic Sea countries, when it comes to their size, can be considered as similar to the Polish banking sector (Table 4). In such a comparison, proportions undergo a radical change, and Poland presents completely different. For example, according to the National Bank of Romania (RNB) data, the total assets of local banks in Romania at the end of 2017 amounted to only 90 bln EUR, which is 4.5 times less than in Poland, while in the case of Bulgaria, the value of Bulgarian banking sector is almost 8 times lower than in Poland (although referring banks' total assets to the number of residents, differences are slightly lower, and the title of regional leader is not for Poland, but for the Czech Republic). The banking sectors in the Baltic countries (Lithuania, Latvia, Estonia) present similar values of banks' total assets, however, they are over 14 times lower in relation to the Polish banking sector. Nevertheless, in terms of values per capita, they significantly (apart from Lithuania) exceed values of bank assets in Poland.

A common feature of all banking sectors is the ongoing consolidation process of the banking sector. The merger processes of a banking sector influence a systematic growth of concentration ratios. In 2008, a share of the 5 largest banks in Poland (PKO BP, Pekao SA, Santander Bank Polska, mBank and ING Bank Śląski) in the whole sector's total assets accounted for $44.6 \%$, in 2013 it was $46 \%$, while in 2017 the balance sheet total of these banks exceeded 100 bln PLN, and their share in the sector's total assets fluctuated around $48 \%$ (see Table 5 ). ${ }^{2}$

Table 5. The share of the largest 5 banks in total assets of the sector (CR5) in 2008-2017

(source: Polish Financial Supervision Authority, 2008-2017)

\begin{tabular}{|c|c|c|c|c|c|c|c|c|c|c|}
\hline & 2008 & 2009 & 2010 & 2011 & 2012 & 2013 & 2014 & 2015 & 2016 & 2017 \\
\hline $\begin{array}{c}\text { Share in total } \\
\text { assets of the } \\
\text { whole sector [\%] }\end{array}$ & 44.6 & 44.2 & 43.9 & 44.3 & 45.0 & 46.1 & 48.5 & 48.8 & 48.3 & 47.8 \\
\hline
\end{tabular}

Concentration ratios of the Polish banking sector show continuous but slight increases, although their level is still quite low compared to other European Union countries. As Figure 2 shows, the values of CR5 ratios place the Polish banking sector at 21 positions among EU countries and are significantly lower than the EU average (62\%). However, this situation may change due to the increasing intensity of mergers and acquisitions (Pawłowska, 2019). It should be pointed out that the capital consolidation of banks in Poland is made mainly with foreign capital. On the other hand, domestic investors engage in this process with strong state capital support (J. Pyka \& I. Pyka, 2018).

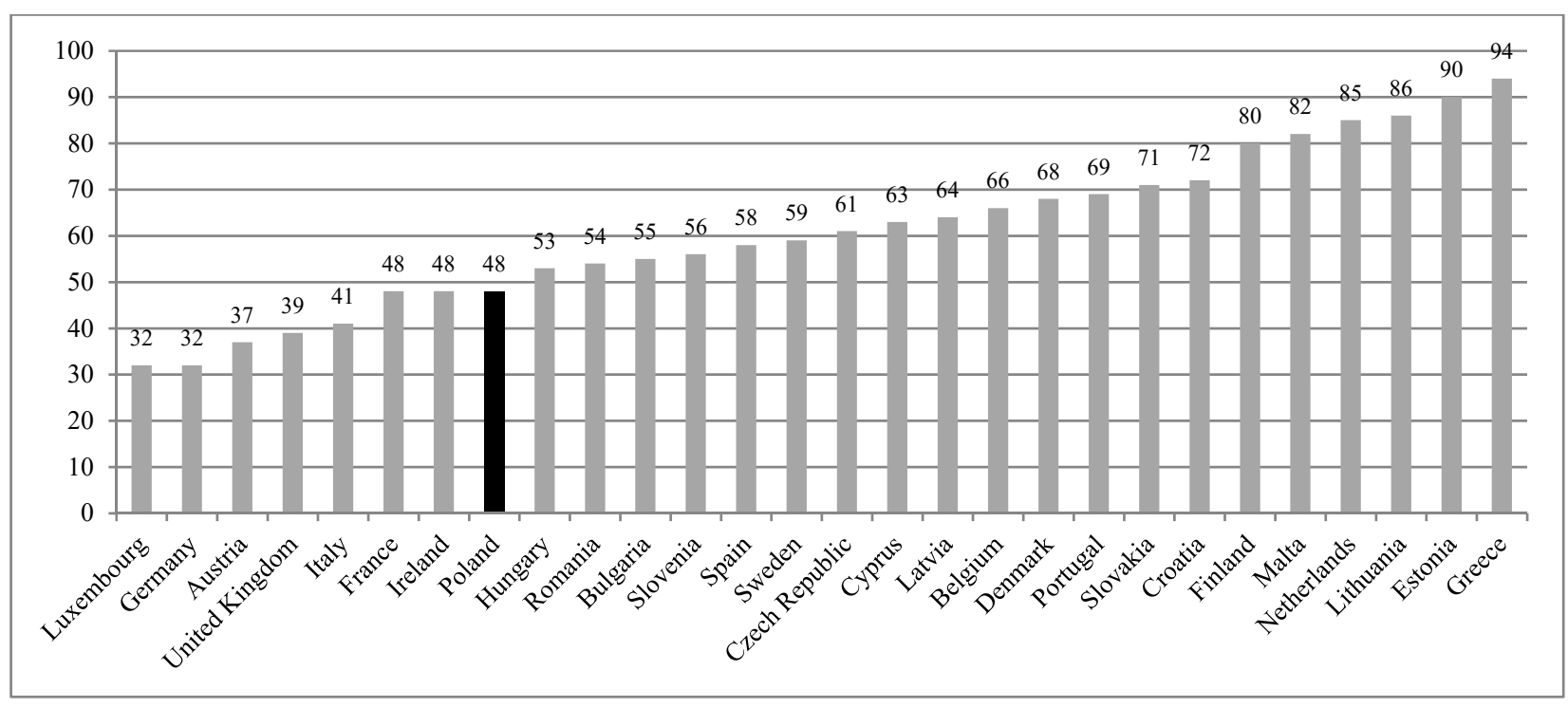

Figure 2. CR5 concentration ratios in Europe in 2017 [\%] (source: Kotowicz, 2015)

The CR5 position of the Polish banking sector, which is distant compared to other European Union countries, indicates that in other EU countries total assets are even more concentrated among the top five banks. In six European countries (Finland, Malta, the Netherlands, Lithuania, Estonia, Greece), the 5 largest banks concentrate over $80 \%$ of the sector's total assets. In Greece, the CR5 index was at a level of $65 \%$ in 2005 , while since 2013 it has

${ }^{2}$ In turn, the top 10 banks (CR10) in Poland manages over $71 \%$ of the total assets of the whole sector, while 7 years ago it was just over $63 \%$. 
been over 94\%. This means that five major credit institutions control almost the whole Greek banking sector (Pawłowska, 2019).

In large European economies (Germany, the United Kingdom, France, Italy) the situation is totally different, where a share of total assets of the 5 largest banks does not exceed 50\%, it even ranges between $30 \%$ and $40 \%$. Luxembourg and Germany are countries with the lower concentration of the banking sector (in terms of their total assets), where the 5 top banks account for approx. 30\% of the total assets of the whole banking sector.

Despite high concentration rates in the analyzed banking sectors, further consolidation expectations in the global economy are strongly emphasized. In turn, further consolidation processes will be reflected in the ownership structure changes in the banking sectors. As can be seen in Table 6, a significant part of the banking sector in Europe in 2017 was concentrated in the hands of domestic investors. Among large sectors (Germany, France, the UK), this share ranges from $63-92 \%$. Foreign investors play a greater role in smaller and weaker, in terms of capital, countries. Although, Luxembourg is an exception - in the years of 2004-2015 a share of foreign investors in the banks' share capital in Luxembourg was very high and amounted to over $96 \%$. This large number of foreign banks is due to the fact that Luxembourg is still perceived as a country with an attractive location for asset management. Banks operating there, specialize primarily in private banking, fund management, and moreover, the banking sector is used as a transmission channel for credit abroad (Cichy \& Puszer, 2016).

Table 6. The ownership structure of bank capital in selected European countries; state as of June 1, 2017 (source: own work based on ECB, BNB, Czech National Bank, Bulgarian National Bank, National Bank of Romania, National Bank of Slovakia and Polish Financial Supervision Authority data)

\begin{tabular}{|c|c|c|c|}
\hline Country & $\begin{array}{c}\text { The share of domestic capital [\%] } \\
\text { state as of June 1, } 2017\end{array}$ & Country & $\begin{array}{c}\text { The share of domestic capital [\%] } \\
\text { state as of June } 1,2017\end{array}$ \\
\hline United Kingdom & 63 & Ireland & 55 \\
\hline Germany & 88 & Portugal & 77 \\
\hline France & 92 & Poland & 56 \\
\hline Spain & 93 & Greece & 98 \\
\hline Italy & 87 & Slovakia & 4 \\
\hline Austria & 73 & Luxembourg & 4 \\
\hline
\end{tabular}

In 2017 in Poland, domestic investors controlled 13 (out of 36) commercial banks (eight banks were controlled by the State Treasury and five by private capital) and all cooperative banks. This represented $56 \%$ of a share of domestic capital in the ownership structure. In 2018, the share increased by $2 \%$ in favour of domestic capital as a result of an acquisition of the second largest bank in Poland - Bank Pekao SA by domestic investors (PZU SA and Polski Fundusz Rozwoju).

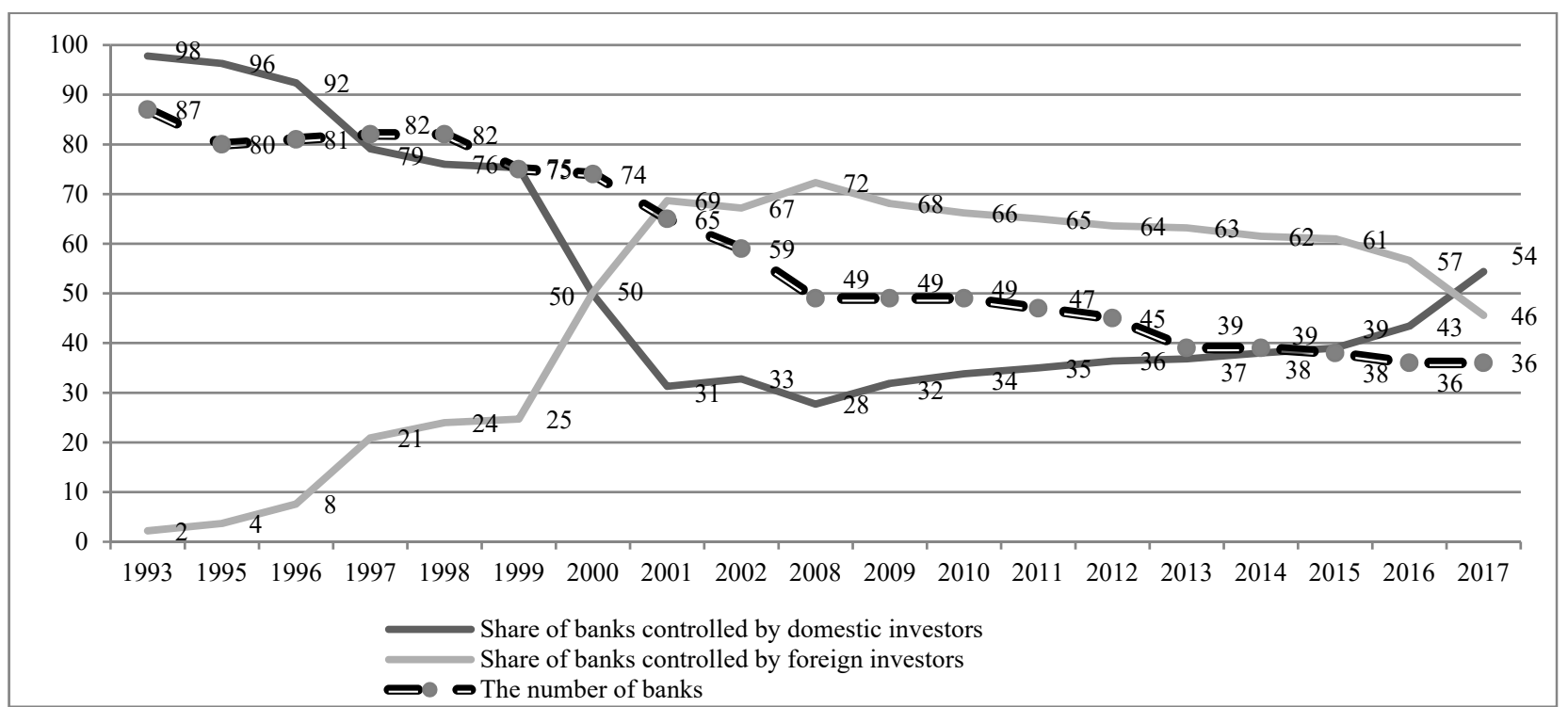

Figure 3. The ownership structure of commercial banks in the Polish banking sector [\%] and the number of commercial banks in the sector [pcs] (source: own work based on Pietrzak, Polański, \& Woźniak, 2004; National Bank of Poland, 2000, 2007; Polish Financial Supervision Authority data) 
It should be noted, analyzing how the ownership structure of Polish banking sector changed between 1993-2017 compared to the ongoing sector consolidation expressed in the number of banks (Figure 3), that with the declining number of banks, a share of foreign investors in the sector's structure decreases. This may mean high activity of domestic investors in taking over bank capital, especially in recent years when the nationalization process of the banking sector in Poland took place.

At the end of 2018, the Polish capital is engaged in 14 institutions, which constitute $54.5 \%$ of the banking market in Poland. Among foreign investors, the largest share $(10.2 \%)$ belongs to institutions from Germany (Commerzbank - owner of mBank, Deutsche Bank) and Spain (Santander - owner of Santander Bank Polska, formerly BZ WBK) which is equal to $8.6 \%$, while France (BGŻ BNP Paribas and Credit Agricole), as well as the Netherlands (ING Group - owner of ING Bank Śląski), represent about 7\% of share. The others, Portugal (Banco Comercial Portugues - owner of Bank Millennium) and the US (Citibank - the owner of Citi Handlowy) hold a share below $4 \%$.

\section{Conclusions}

The banking sector in Poland is growing at a rate significantly exceeding the growth rate in other European countries. However, rapid development does not mean a radical increase in the importance of this sector in Europe, both when considering the size of the sector's total assets and the value of banking assets per capita. In such a situation, comparing the size and strength of the European banking sectors may not present an objective view in relation to the banking sector in Poland. Differences mainly result from a short period of the Polish banking sector functioning in free market conditions (about 20-25 years) as opposed to the banking services market in Germany, France, Italy or Switzerland, which have a several-hundred-year tradition.

The most similar (historically and in size) to Poland are banking sectors of Central and Eastern Europe, such as Slovakia, Romania, Hungary or the Baltic states. However, it turns out that in terms of total assets, only the Czech Republic among Central European banking sectors are able to compete with the Polish banking sector.

In addition to the rapid development of the sector, it should be emphasized the fact of increasing degree of sector's consolidation after the global financial crisis of 2008-2012. The result of the consolidation trend is a systematic increase in concentration ratios, although levels of consolidation ratios of the banking sector in Poland are still quite low compared to other EU countries. Thus, further capital consolidation and changes in the ownership structure in the Polish banking sector are expected. This will be favored by (J. Pyka \& I. Pyka, 2018):

- international trend and changes in the banks' regulatory environment, often resulting in their new business models,

- high fragmentation of their operational activity, compared to the banking market in Western Europe (there are several dozen financial institutions operating on the Polish banking market, which in the long term are not able to compete with larger banks),

- the unfavorable trend of banks' profitability observed since 2008 (the strongest in terms of capital commercial banks with high profitability, may strive to improve their competitive position by taking over clients of less-profitable banks, which may lead them to exit from the market).

Consolidation processes of banking sectors are reflected in changes in the ownership structure of the sector. In Europe, in large banking sectors, assets are concentrated mainly in the hands of domestic investors, while in smaller and weaker countries foreign investors play a greater role. In Poland, the decreasing number of banks also reduces a share of foreign investors in the structure of the sector. This means the high activity of domestic investors in taking over bank capital.

Despite the decline in profitability of the European banking sector observed after the financial crisis in 2008-2012, it should be emphasized that the Polish banking sector is distinguished by its very high efficiency. Banks operating in Poland achieve significantly better rates of return from invested capital compared to banks in other countries. ${ }^{3}$ Maintaining a high rate of growth of the banking sector in Poland while continuing current efficiency will undoubtedly be a challenge for banks operating in Poland in the coming years.

\section{References}

Al-Malkawi, H. N., Marashdeh, H. A., \& Abdullah, N. (2013). Financial development and economic growth in the UAE: Empirical assessment using ARDL approach to co-integration. International Journal of Economics and Finance, 4(5), 105115. https://doi.org/10.5539/ijef.v4n5p105

Avery, R. B., Bostic, R. W, Calem, P. S., \& Canner, G. B. (1999). Trends in home purchase lending: Consolidation and the Community Reinvestment Act (Federal Reserve Bulletin, Tom 85, No. 2, pp. 81-102). Washington.

\footnotetext{
${ }^{3}$ Return on Equity (ROE) ratio for banks in Poland in recent years exceeded $10 \%$ and was one of the highest in Europe. For comparison, German, Dutch or British banks maintained this indicator at the level of about $4 \%$ (in the case of Italy, Portugal or Cyprus its value was even negative).
} 
Berger, A. N., Demsetz, R. S., \& Strahan, P. E. (1999). The consolidation of the financial services industry: causes, consequences, and implications for the future. Journal of Banking and Finance, 23, 135-194.

https://doi.org/10.1016/S0378-4266(98)00125-3

Cichy, J., \& Puszer, B. (Eds.). (2016). Sektory bankowe w Unii Europejskiej [European Union banking sectors]. University of Economics in Katowice Publishing House, Katowice.

Doan, A.-T., Lin, K.-L., \& Doong, S.-C. (2018). What drives bank efficiency? The interaction of bank income diversification and ownership. International Review of Economics \& Finance, 55, 203-219. https://doi.org/10.1016/j.iref.2017.07.019

Europe primed for wave of banking consolidation. (2018, July 1). The banker. London.

Financial Service Agency. (2002). Koho Kona (in press, Vol. 23.) Tokyo.

Flejterski, S., \& Wahl, P. (2010). Globalizacja - stare i nowe dylematy u progu drugiej dekady XXI wieku. Globalizacja. Liberalizacja. Etyka (Working Papers No. 607, Modern Economics Problems, pp. 14-20). University of Szczecin Publishing House.

Greenwood, J., Sanchez, J. M., \& Wang, C. (2013). Quantifying the impact of financial development on economic development. Review of Economic Dynamics, 16, 194-215. https://doi.org/10.1016/j.red.2012.07.003

Hasan, I., \& Marton, K. (2003). Development and efficiency of the banking sector in a transitional economy: Hungarian experience. Journal of Banking \& Finance, 27, 2249-2271. https://doi.org/10.1016/S0378-4266(02)00328-X

Horvatova, E. (2018). Technical efficiency of banks in central and Eastern Europe. International Journal of Financial Studies, 6(66), 1-25. https://doi.org/10.3390/ijfs6030066

Jackson, O. (2018, July 5). Consolidation and the EU banking sector. International Financial Law Review. London.

Jansen, D., \& de Haan, J. (2003). Increasing concentration in European banking: a macro-level analysis. In Research Memorandum WO. De Nederlandsche Bank. https://doi.org/10.2139/ssrn.518422

Kotowicz, A. (2015). Koncentracja sektora bankowego [Banking sector concentration]. Department of commercial and specialist banking and payment institutions, Office of the Polish Financial Supervision Authority, Warsaw.

Matoušek, R., \& Taci, A. (2004). Efficiency in banking: empirical evidence from the Czech Republic. Economic Change and Restructuring, 37, 225-244. https://doi.org/10.1007/s10644-005-5059-4

National Bank of Poland. (2000, April). Sytuacja finansowa banków w 1999 r. Synteza [Financial situation of banks in 1999. Synthesis]. Warsaw.

National Bank of Poland. (2007, July). Sytuacja finansowa banków w 2006 r. Synteza [Financial situation of banks in 2006. Synthesis]. Warsaw.

Pawłowska, M. (2019, March). W poszukiwaniu optymalnego poziomu konkurencji w sektorze bankowym [In search of an optimal level of competition in a banking sector]. Retrieved from https://www.obserwatorfinansowy.pl/tematyka/bankowosc/wposzukiwaniu-optymalnego-poziomu-konkurencji-w-sektorze-bankowym

Pietrzak, B., Polański, Z., \& Woźniak, B. (Eds.). (2004). System finansowy w Polsce [Financial system in Poland]. PWN, Warsaw.

Pohl, M., Tortella, T., \& Van der Wee, H. (Eds.). (2001). A century of banking consolidation in Europe: the history and archives of mergers and acquisitions. Aldershot.

Polish Financial Supervision Authority. (2008). Raport o sytuacji banków w 2007 [Report on the condition of banks in 2007]. Warsaw.

Polish Financial Supervision Authority. (2009). Raport o sytuacji banków w 2008 [Report on the condition of banks in 2008]. Warsaw.

Polish Financial Supervision Authority. (2010). Raport o sytuacji banków w 2009 [Report on the condition of banks in 2009]. Warsaw.

Polish Financial Supervision Authority. (2011). Raport o sytuacji banków w 2010 [Report on the condition of banks in 2010]. Warsaw.

Polish Financial Supervision Authority. (2012). Raport o sytuacji banków w 2011 [Report on the condition of banks in 2011]. Warsaw.

Polish Financial Supervision Authority. (2013). Raport o sytuacji banków w 2012 [Report on the condition of banks in 2012]. Warsaw.

Polish Financial Supervision Authority. (2014). Raport o sytuacji banków w 2013 [Report on the condition of banks in 2013]. Warsaw.

Polish Financial Supervision Authority. (2015). Raport o sytuacji banków w 2014 [Report on the condition of banks in 2014]. Warsaw.

Polish Financial Supervision Authority. (2016). Raport o sytuacji banków w 2015 [Report on the condition of banks in 2015]. Warsaw.

Polish Financial Supervision Authority. (2017). Raport o sytuacji banków w 2016 [Report on the condition of banks in 2016]. Warsaw.

Polish Financial Supervision Authority. (2018a). Raport o sytuacji banków w 2017 [Report on the condition of banks in 2017]. Warsaw.

Polish Financial Supervision Authority. (2018b). Raport o sytuacji banków w okresie I-IX 2018 roku [Report on the condition of banks in the period of January-September 2018]. Warsaw.

Polish Financial Supervision Authority. (2018c). Sytuacja sektora bankowego w 2017 [Situation of the banking sector in 2017]. Warsaw. 
Pyka, I., Cichy J., Nocoń, A., \& Pyka, A. (2018). Repolonizacja banków w Polsce. Przesłanki, założenia i dylematy zmian własnościowych [Repolonization of banks in Poland. Premises, assumptions and dilemmas of ownership changes]. Difin, Warsaw.

Pyka, J., \& Pyka, I. (2018). Procesy konsolidacji kapitałowej w polskim sektorze bankowym po globalnym kryzysie finansowym [Processes of capital consolidation in the Polish banking sector after the global financial crisis]. Working Papers of the Silesian University of Technology, Series: Organization and Management, 118, 482, 488-489.

https://doi.org/10.29119/1641-3466.2018.118.36

Seo, M., \& Hill, N. S. (2005). Understanding the human side of merger and acquisition: An integrative framework. Journal of Applied Behavioral Science, 41(4), 422-443. https://doi.org/10.1177/0021886305281902

Shih, S. H. M. (2003). An investigation into the use of mergers as a solution for the Asian banking sector crisis. The Quarterly Review of Economics and Finance, 43(1), 31-49. https://doi.org/10.1016/S1062-9769(01)00135-1

Tsaurai, K. (2017). Financial market performance: An influence of personal remittances. Corporate Ownership and Control, 14(2), 268-273. https://doi.org/10.22495/cocv14i2c1p13

Zingales, L., \& Raghuram, G. (2003). Banks and markets: the changing character of European Finance. Paper presented at the European Central Bank 2nd Annual Conference 2002, Frankfurt am Main. https://doi.org/10.3386/w9595 